\title{
THE USE OF DRONES DURING MASS EVENTS
}

\author{
Marlena Robakowska ${ }^{1}$, Anna Tyranska-Fobke ${ }^{2}$, Joanna Nowak ${ }^{3}$, Daniel Slezak ${ }^{4}$, \\ Przemysław Zuratynski ${ }^{4}$, Piotr Robakowski ${ }^{5}$, Klaudiusz Nadolny ${ }^{6,7}$, Jerzy Robert Ladny ${ }^{7}$ \\ ${ }^{1}$ Medical University of Gdansk, Faculty of Health Sciences, Department of Public Health \& Social Medicine \\ ${ }^{2}$ Medical University of Gdansk, Faculty of Health Sciences, Second Department of Radiology \\ ${ }^{3}$ Medical University of Gdansk, Faculty of Health Sciences \\ ${ }^{4}$ Medical University of Gdansk, Faculty of Health Sciences, Emergency Medicine Workshop \\ ${ }^{5}$ University of Gdansk, Faculty of Social Sciences \\ ${ }^{6}$ Provincial Rescue Service in Katowice \\ ${ }^{7}$ Medical University of Bialystok, Department of Emergency Medicine and Disasters
}

\begin{abstract}
The concept of a mass event has been defined by the law on mass event security. The use of drones to monitor events involves numerous benefits. Surveillance provided by means of drones is particularly beneficial as far as large open areas are concerned. Unmanned aerial vehicles (UAVs) alert one to any issues in the crowd.
\end{abstract}

KEY WORDS: unmanned aerial vehicles, drones, mass events

Disaster Emerg Med J 2017; 2(3): 129-134

The definitions of mass events are included in the Law of 20 March 2009 on mass event security [1]. Mass events may include arts events, entertainment and sports events [1]. The definition excludes events that are organized in places such as theatres, opera houses, museums, and other events specified in the act [1]. These regulations also exclude internal events organized by employers, educational institutions, as well as competitions for disabled people [1]. The building or area hosting the event needs to meet the expectations required by the character of the event [1]. An event can be called a mass event depending on the number of participants in the particular event [1]. The type of event, place and level of risk are also characteristic factors in defining a mass event [2].

An arts-entertainment event organized in a stadium or in other suitable area may be called a mass event when the number of places for participants is not lower than 1000 [1]. There are also situations when events are organized in sports halls or other properly adapted buildings [1]. In this case, the location needs to have at least 500 places available in order for the event to be called a mass event. [1]. There are other criteria in the case of sports events. For sports events organized in stadiums or other similar buildings and areas, 1000 expected participants is the minimum required to call the sports event a mass event [1]. The minimum is lower [300 participants] for events taking place in sports halls or other buildings [1]. Events with a lower capacity are not defined as mass events [1]. The capacity of the building is identified according to fire protection regulations and construction law [1].

The obligation to secure the mass event is imposed on the organizer [1]. Providing the event with medical services is one of the elements of this responsibility [2]. The relevant regulations and requirements to be fulfilled have been described in the Regulation of the Minister of Health of 6th February 2012 on the minimum requirements concerning medical security of mass events [3]. Additional elements of the emergency medical system are required to ensure security and appropriate medical care at the site of event. Medical security involves prehospital teams, rescue patrols and points of medical assistance properly situated, depending on the character of the event [3]. The number of required security 
units varies depending on the capacity of the venue [2]. The capacity is also a criterion indicating the composition of the specific medical security unit [3]. Depending on the scale of the event, some of the prehospital teams may include only paramedics [basic emergency medical unit]. A doctor is required in the team in the case of a mass event for which the number of places made available by the organizer for participants is higher than 5,000, and in the case of an increased risk mass event [3]. Such a team (with a doctor) is called a specialized emergency medical unit. The higher the number of participants, the greater the demand for emergency medical units. The above-mentioned criteria also influence the required number of rescue patrols, with one rescue patrol being required for a small mass event. When the number of places made available by the organizer for participants is higher than 5000 , one patrol is required for each 10000 participants [4]. The Regulation of the Minister of Health cited above also defines the required number of points of medical assistance and the equipment to be available [3].

In order to improve the flow of information during a mass event with the number of participants exceeding 100,000, the organizer appoints one individual to act as a medical coordinator [3]. This function can be assigned to a paramedic, a doctor or a nurse [3]. Another condition is that a medical coordinator needs to have at least 5 years of experience within the system of Emergency Medical Services [3]. All services securing a mass event should be provided with wireless connectivity devices [3]. Such devices enable the constant exchange of information between service units and organizers. The flow of information is extremely important in cases of hazards and accidents during mass events. Owing to effective communication, procedures can be quickly implemented and the proper casualty evacuation route can be indicated [5]. The use of drones during mass events may significantly shorten the time needed to reach the casualty [6]. Thus, drones can supplement the functions of medical services [6].

Vision delivers most of our information (up to $80 \%$ ) about the human environment [7]. This incredibly important sense enables paramedics to observe a particular area and provide a prompt reaction in case of situations dangerous to life or health. During mass events, there are also limits and obstacles that may not always be overcome by human sight. Surveillance providing security for participants in an event is the essence of medical security [2].
Frequently, there are obstacles e.g. a vast area, the topography, the large number of participants and other conditions of the environment that hinder the work of paramedics and other security services. [6]. The time of the day also affects the proper adjustment of medical security [2]. Visibility is limited after dark and vision starts to adapt to darkness [7]. Depending on the lighting of the mass event area, the image of one's surrounding may become distorted, which hinders general orientation [8]. Air temperature is another factor having impact on the efficiency of medical security [9]. In high daytime temperatures, cases of overheating of the body that require medical intervention are much more frequent. This hinders prompt reactions of paramedics to any other life-threatening situations. Vast areas covered by the mass event do not facilitate the situation.

UAVs cannot replace the human element [6]. However, they can facilitate the processes of medical security, particularly in cases described in the above paragraph. The visibility range of a drone is higher that the visibility from the perspective of a person in the crowd [9]. Depending on image quality, the stability of the device and zooming, UAVs can significantly support the evaluation of a situation in the area of a mass event [6]. These devices are able to identify dangers faster than paramedics [6]. The reasons for this advantage is that they have a broader angle of view and the possibility of observing larger areas [6]. What is more, drones are resistant to high temperature and any substances toxic to humans [10]. Drones can register and transmit images in real time, which makes them an ideal recognition tool that minimizes the risk of damage to the health of paramedics [1].

Moreover, it is beneficial to employ UAVs to visualize the area before the medical event. This makes it possible to analyze the potential distribution of escape routes and points of medical assistance [11]. The person monitoring the image delivered by the drone camera can advise ambulances and other security services on how to efficiently reach a given destination [12]. UAVs can also support medical services in locating the casualties in areas with limited access [6]. The possible obstacles include topography, the large number of participants and any danger that makes it impossible to locate casualties from ground level [13]. Scientists from the John Hopkins University in Maryland have developed a system that, according to their research, is the most efficient system of security evaluation of the 
area to be monitored [12]. In this process, the team uses two drones and a compatible laptop that projects the images delivered by both drones [12]. UAVs are able to monitor a much larger area that the human eye owing to a high camera resolution [12]. First, a particular area or place is selected on the screen view [12]. Owing to advanced navigation technology, drones are later navigated by means of a special software [12]. The system allows two UAVs with different flying height parameters to facilitate observations. [12]. The altitude of the first drone is about $120 \mathrm{~m}$, which ensures a wide range of monitoring view [12]. The altitude of the second drone is $30 \mathrm{~m} \mathrm{[12].} \mathrm{In} \mathrm{the} \mathrm{case} \mathrm{of} \mathrm{any} \mathrm{identified} \mathrm{issues,}$ the second drone delivers a detailed image of the particular situation or element of the mass event in order to quickly recognize the potential danger [12]. In some cases, one monitoring drone is enough, depending on the structure of mass security system, the number of participants and the size of the drone monitoring team [14].

There are specific requirements for organizers to be able to use UAVs during medical security events [6]. The device needs to enable the viewing of high resolution images in real time [15]. Moreover, the UAV operator needs to have the possibility of zooming control [by means of optical zoom] from ground level [15]. On the technological market, there is a wide choice of cameras that meet these expectations, with the V18 Yuneec with $18 x$ zoom being a camera recommended for such purposes [15]. Although using devices with poorer zooming parameters is not an obstacle, it hinders the detailed monitoring of events [6]. The FPV (first person view) transmitter sends the signal from the device to the operator [15]. The maximum time of a single drone flight is a very important aspect [16]. This parameter enables constant control of the mass event and monitoring of the flow of participants. There are numerous companies that offer UAVs with about 40 min flight time [15]. There are only few commercial devices available that are characterized by longer flight time parameters [12]. This means that an operator needs to be equipped with a specific number of replacement batteries depending on the time of the event [6]. In the case of marathons, regattas and other dynamic events, the option of drone mission planning is useful [11]. This function enables one to plan and fulfil the mission [11]. Another basic important parameter is image stabilization [6]. UAVs are equipped with gimbals that are elements maintaining the stability of the device [15]. Gimbals need to ensure image stability in all axes of the device in order to enable observation in changing weather conditions [8]. This enables transmitting detailed images, identifying people and rapid danger recognition.

Proper planning of the system of security service procedures is an important element of appropriate mass event security. The aim of a mass event security is to ensure the safety of the participants in the event. Identifying potential threats that the event may involve is a significant point. Such identification enables one to minimize dangers and ensure proper medical security preparation [5]. The state of health of the participants in the event is influenced by weather conditions. High temperatures are usually related with fainting and cases of sunstroke [9]. Consumption of alcohol and intoxicants by participants of the event is also an important factor [9]. In cases of poisoning and loss of consciousness, the prompt reaction of medical services is crucial [5]. There may be various types of dangers depending on the type of event, the age of the participants and the number of people gathered in the area [17]. For instance, cases very typical of concerts are related with the physical pressure of the crowd [9]. Sometimes accidents can be of mass character and require special organization and the engagement of medical and security services [9]. Any potential accident threat hinders the work of medical personnel securing the mass event.

In life-threatening situations, the time needed to provide medical assistance plays a significant role [5]. Therefore, the ability to locate the casualty is a crucial element that influences the health and safety of the participants [2]. Locating the injured party is an element of the so-called "golden hour" [18]. The "golden hour" is a period that starts as soon as the injury or the threat has occurred [5]. It is said that, in the case of traumatic injuries, there is the highest likelihood that surgical intervention within this hour will prevent death [5]. The reasons for hospitalization during mass events has been analyzed in Australia for more than a decade [19]. Indeed, an arts event with over 600,000 participants became the subject of one particular study [19]. During this event, paramedics were involved in 1,000 cases of individuals with various health problems [19]. Most of these patients [26\%] had been injured [19]. Injury is the most frequent reason for medical interventions at mass 
events [19]. Within this group of injured participants, 5\% required hospitalization [19].

In the case of casualties who require hospitalization, the prehospital period at the event site has a particular impact on the patient's health [5]. Monitoring events by means of drones may shorten the time that casualties have to wait for specialized medical assistance. Owing to constant monitoring of participant in events, UAVs can significantly accelerate the process of locating individuals who require medical assistance [9]. This is related with the faster implementation of medical procedures that increases the chances of a therapeutic benefit [5]. Having a wider range of observation possibilities, a drone operator is able to advise emergency medical units on how to efficiently reach the accident site [13]. Activating the emergency response system is the most important element of the "chain of survival" and can significantly minimize the effects of the injury [18]. According to the literature, the time that it takes an ambulance to reach an accident site should not exceed 15 minutes. Therefore, efficient planning of access and evacuation routes is crucial in the further treatment process [5].

Prompt reaction to situations involving casualties minimizes the negative reactions of witnesses during a mass event [17]. A long period of waiting for an emergency response leads to panic and chaos that may cause further accidents [17]. Crowds are common during mass events and usually do not lead to any serious issues. Sometimes areas are overcrowded and poorly managed, which causes injuries or even fatalities [17]. It has been found that there are two key factors preventing overcrowding, namely: real time transmission of information on the situation during a mass event and communication among security services [17]. Drone-based monitoring appears to be an ideal solution that enables alerting one to overcrowded areas [17].

To some extent, the operator's tasks while monitoring mass events are more difficult than tasks related to common commercial flights [20]. In order to monitor mass events, the operator needs to be familiar with the specific UAV flight regulations of a given country's airspace and be aware of other factors that ensure a secure flight [6]. This means that the human element should be strongly emphasized in drone exploitation [10]. Multicopters may be dangerous when operated by an unqualified operator [21]. Being familiar with regulations and all technical parameters is crucial in providing successful flights and effective observations [6]. All the required information regarding UAV flight security issues are available on the official website of the Civil Aviation Office [22]. However, despite the drone operator's skills, drone-based monitoring of mass event may sometimes be inefficient or impossible [8].

Similarly to other airmen, drone operators always need to consider weather conditions in the area where they plan to use flying equipment [8]. In order to ensure the secure landing of a UAV, the operator needs to obtain information about wind speed and direction as the wind is a factor that hinders stable operation of the vehicle [8]. Dangerous weather conditions such as freezing rain and storms may disturb the flight of the drone and the monitoring of a particular area [8]. Owing to detailed weather analysis, operators and pilots are able to decide when devices can be used. The identification of clouds and rain additionally helps to decide if weather conditions enable the safe take off of the device [8]. Real time observation of the area is also of great importance [6]. A significant factor in the drone-based monitoring of mass events is considering the planned flight route and locating the most crowded areas [23]. Flying devices hovering directly over the audience are dangerous in case of any sudden technical fault of the machine [6]. Therefore, due to security issues, the event should be monitored from areas that enable drone landing [8].

While using the drone, the operator has to be prepared for potential technical issues [10]. In order to avoid them, the entire flying apparatus needs to be checked before the flight [23]. The safety of UAV flights mostly depends on the quality of the technical components of the device [10]. However, the most important factor is the human element because it is the operator who is expected to react to any faults and decide if the flight should be continued [10]. The operator's skills are particularly important due to the separation of the aerial device from the human element, which leads to a situation where the operator is deprived of a series of sensory channels [10]. Instead of direct observation of the environment, the operator receives information transmitted by on-board sensors [10]. In commercial use, it is safer to operate flights within one's visual line of sight [10]. Thus, the checking of the technical condition of the device prior to flight is good practice [22]. The elements that require checking are propellers, compass calibration, diodes, batteries 
and the condition of the engines [16]. Most of UAVs are equipped with failsafe systems that enable operators to regain control over drones or make it possible for drones to return to the take-off platform without assistance [16]. Another helpful feature is ensured by 'detect and avoid' modules that enable manoeuvres between other flying objects in the airspace [23]. An important piece of information for operators is that devices launched by the DJI company are equipped with blocking systems preventing devices from flying in forbidden areas [16].

UAV-based monitoring during mass events is not always effective at night [7]. Although drones with thermo-vision cameras are available, they do not have any significant impact on the location of the casualty in the crowd during a mass event [15]. Such drones are useful in rescue missions involving casualties of natural disasters and in situations when it is very difficult for the casualty to be located in a large and empty space [15]. In the case of proper outdoor lighting of a mass event organized at night, a thermo-vision drone camera is not necessary.

Some countries provide clear regulations regarding UAV flights whereas other do not [24]. There are also many laws and regulations that are out-of-date because of the dynamic development of the sector and the need for constant updates [6]. For instance, commercial UAV flights are currently not allowed in Belgian airspace [24]. Only models attested by the Directorate-General for Aviation may be tested [24]. Also in Ireland the testing of drones is not allowed without the clear consent of the Aviation Office, while all UAV models need to be officially registered [24]. There are also such countries where there are no specified requirements that should be fulfilled in order for operators to be able to operate UAV flights [24].

The definition of mass events is included in the 2009 law on mass events security [1]. The classification of mass events depends mainly on the range of the events, the number of participants and the level of risk [1]. The medical security of mass events is an essential element of events that is regulated in a Regulation of the Minister of Health of 2012 [2]. The application of the drone-based monitoring of events is beneficial, particularly in large areas [6]. UAVs alert one to any issues in the crowd [25]. This enables security services to locate casualties and implement medical procedures. The visibility range of a drone is higher than that from the perspective of a person in the crowd [6]. The presence of a crowd is another factor that limits visibility from the human point of view, and one which supports the idea that UAVs can significantly facilitate medical security processes. Area observation, distribution of rescue routes and the assessment of potential risks in the environment are therefore clearer and more precise [6]. Time is a crucial factor in the case of life-threatening situations [5]. Owing to real time transmission of information from a drone to a stationary device, an operator has the possibility to alert patrols and points of medical assistance before third parties do this. A prompt response increases the therapeutic chances of the patient by means of ensuring their earlier hospitalization [5]. However, it is not always possible to employ UAVs. The decision depends on the site of the event, weather conditions, the operator's experience and the technical condition of the device [10]. Legal issues may constitute another potential obstacle as UAV flights are illegal or unregulated in some countries [26]. Nevertheless, the number of advantages which UAVs possess definitely exceeds any disadvantages. Drones are going to become one of the elements of medical security owing to detailed analyses and research devoted to the monitoring of mass events [6].

In some situations, drone-based monitoring technology may be helpful in maintaining public order [1]. An example is the possibility to register any suspicious behaviour, movement of groups or individuals, as well as any potentially dangerous use of objects. Current technology provides a comprehensive surveillance system with various possibilities to patrol and inspect given areas [25]. Proximity and visibility (not distance) should be the starting point in the analysis of using UAVs in the medical sector [27].

Conflict of interest: None declared.

\section{REFERENCES}

1. Ustawa z dnia 20 marca 2008 r. o bezpieczeństwie imprez masowych. T.j. Dz.U. z 2009 r. Nr 62, poz. 504.

2. Szymonik A. Logistyka imprez masowych. Politechnika Łódzka, Warszawa 2011

3. Rozporządzenie Ministra Zdrowia z dnia 6 lutego 2012 r. w sprawie minimalnych wymagań dotyczących zabezpieczenia pod względem medycznym imprezy masowej. T.j. Dz.U. z 2012 r., poz. 181.

4. Wojciechowski R. Bezpieczeństwo uczestników imprez masowych. Zeszyty Naukowe Uniwersytetu Przyrodniczo-Humanistyczengo w Siedlcach. 2013; 97: 179. 
5. Campbel J. International Trauma Life Support. Medycyna Praktyczna, Kraków 2009.

6. Gontarz A, Kosieliński S. Rynek dronów w Polsce 2015. Księga popytu i podaży. Instytut mikroMAKRO, Warszawa 2015.

7. Owczarek M, Węda A. Prowadzenie rozpoznania w warunkach nocy i ograniczonej widoczności. Wyższa Szkoła Oficerska im. Tadeusza Kościuszki, Wrocław 2000.

8. Nelson L. More Than Just a Weather Forecast: The Critical Role of Accurate Weather Data in UAV Mission. Defence Update 2015; http:// defense-update.com/features/2009/june/weather_and_uav_operations.html [access: 2017-09-01].

9. Milsten A, Maguire B, Bissell $R$, et al. Mass-Gathering Medical Care: A Review of the Literature. Prehospital and Disaster Medicine. 2012; 17(3): 151-162, doi: 10.1017/s1049023×00000388.

10. McCarley J, Wickens C. Human Factors Concerns In UAV Flight. Aviation Human Factors Division University of Illinois, Illinois 2014.

11. Normand JM. Bientôt des drones de surveillance pour la préfecture de police. Le monde. 2016-03-31. www.drones.blog.lemonde.fr [access: 2017-09-01].

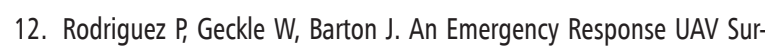
veillance System. AMIA 2006 Symposium Proceedings-Johns Hopkins University, Baltimore 2006: 1078.

13. Kongsberg Geospatial, Renfrew County Paramedics Conduct Successful Beyond Line-of-Sight Field . Trial of Rescue Drone Technology 201603-24. www.kongsberggeospatial.com [access: 2017-09-01].

14. Hodapp P. Search and Rescue Teams Aim to Save Lives with Off-theShelf Drones. We Are All Makers 2015-12-15.

15. Drony dla służb. Nadzór imprez masowych 2016. www.dronydlasluzb. pl [access: 2017-09-01].

16. Adamczyk D. Raport: Drony w Akcji. Time4Mobi. 2015.
17. Fruin J. The causes and prevention of crowd disasters. Elsevier Science Publishers, London 2002.

18. Brongel L. Złota godzina - czas życia, czas śmierci. Wydawnictwo Medyczne, Kraków 2007.

19. Zeitz K, Zeitz C. Injury occurences at a mass gathering event. Australian Journal of Paramedicine . 2002; 3(1).

20. Tworus D. Dusza operatora drona. Polska Zbrojna. 2014; 1(11): 68-69.

21. Gontarz A, Kędzierska E, Kosieliński S, et al. Człowiek Maszyna Bezpieczeństwo. Systemy Inteligentne w zarządzaniu kryzysowym i działaniach militarnych. Instytut mikroMAKRO, Warszawa 2013.

22. Urząd Lotnictwa Cywilnego: Remotely Piloted Aircraft Systems in Poland - Report on the current legal status relating to unnmanned aerial vehicles. Civil Aviation Authority, Warszawa 2013.

23. Cywilne wykorzystanie dronów. Wydawnictwo Sejmowe dla Biura Analiz Sejmowych, Warszawa 2015.

24. Sawicki P. Bazzałogowe aparaty latające UAV w fotogrametrii i teledetekcji. Stan obecny i kierunki rozwoju. Uniwersytet Warmińsko-Mazurski w Olsztynie, Olsztyn 2012.

25. Reagan J. This Week in Public Safety Drones 2016-02-12. https:// dronelife.com/2016/02/12/this-week-in-public-safety-drones/ [access: 2017-09-01].

26. Rozporządzenie Ministra Transportu Budownictwa i Gospodarki Morskiej z dnia 26 marca 2013 w sprawie wyłączenia zastosowania niektórych przepisów ustawy - Prawo lotnicze do niektórych rodzajów statków powietrznych oraz określenia warunków i wymagań dotyczących używania tych statków. T.j. Dz.U. z 2013 r., poz. 440.

27. Karlsrud J, Rosen F. In the Eye of the Beholder? The UN and the Use of Drones to Protect Civilians. Stability: International Journal of Security \& Development. 2013; 2(2): 27: 1-10, doi: 10.5334/sta.bo. 